\title{
Characterization of Water Quality Indicators in the Micro-basin of the Arizona River, Atlántida (Honduras)
}

\author{
Luis Antonio Beltrán Alemán ${ }^{1,2}$, Ismael Montero Fernández ${ }^{3}$, Selvin Antonio Saravia Maldonado², \\ Dixon Nohel Morales López ${ }^{2}$, José David Portillo Villanueva ${ }^{2} \&$ Nelson Edmundo Arriaga Pérez ${ }^{2}$ \\ ${ }^{1}$ Post-Graduate Program in Natural Resources, Federal University of Roraima, Campus Paricarana, Boa Vista, \\ RR, Brazil \\ ${ }^{2}$ Universidad Nacional de Agricultura, Carretera del Dulce Nombre de Culmi, km 215, Barrio El Espino, \\ Catacamas-Olancho, Honduras \\ ${ }^{3}$ Postgraduate Program in Biodiversity and Biotecnology, State Coordination of Roraima, Federal University of \\ Roraima, Campus Paricarana, Boa Vista, RR, Brazil \\ Correspondence: Luis Antonio Beltrán Alemán, Post-Graduate Program in Natural Resources, Federal \\ University of Roraima, Paricarana Campus, CEP 69304-000, Boa Vista, RR, Brazil. Tel: 55-959-8408-6087. \\ E-mail: luisbletran966@yahoo.com
}

Received: June 29, 2018

doi:10.5539/jas.v11n6p394
Accepted: March 28, 2019 Online Published: May 15, 2019

URL: https://doi.org/10.5539/jas.v11n6p394

\begin{abstract}
The water quality was studied in the basin of the Arizona River, supplier of the urban helmet of the municipality of Arizona, department of Atlántida (Honduras). In order to determine the quality of the water provided to the population. The methodology implemented consisted in carrying out tours in the area to obtain information on the delimitation, maps of land uses using tools of the geographic information system (GIS), then it was determined to assign the sampling sites for the three days for three months being the the following: take, storage tank and three taps of the urban center of the municipality of Arizona. The analytical parameters for the micro-watershed (site work) were evaluated and analyzed by the NSF ICA with a multivariate statistical analysis of principal component methods, the remaining analyzes were developed in comparisons according to the admissible values of the Standard Technique for the Quality of Drinking Water of Honduras 1995.
\end{abstract}

Keywords: land use, ICA, anthropization, basin

\section{Introduction}

Water is a natural resource of economic, strategic and social value, essential for the existence and well-being of the human being, as well as a good for humanity, useful for the maintenance of the planet's ecosystems (Uniagua, 2001). Given its importance for the development of life, and due to its unique characteristics, where no process occurs without direct and indirect action, it is essential that its presence in the environments an appropriate quality for its use (Rebouça, 2002).

Given that in recent years there has been a large population growth, thus diversifying the uses of water, have generated unwanted environmental conditions, such as the growth of the number of solid waste and other anthropogenic activities that accelerate the degradation of quality of water, being a worrisome situation, since according to the United Nations World Report on Water Resources Development in 2017 in Latin America only $8 \%$ of wastewater is subjected to some type of treatment.

In Honduras, there is a standard that regulates the quality control of drinking water, called the National Technical Standard for the quality of drinking water of July 31, 1995, where the methods of analysis are specified, as well as the frequency and number of samples required to establish the quality control and the evaluation of the different measurement parameters.

The microbasin of the Arizona River, is the object of study in this work, a river that is born in the community of Zanzibar (Honduras), running its course in a rugged topography with slope of $15-30 \%$ and influenced by the presence of broadleaved forests humid and presence of oxisolos with low fertility (Municipal Atlas and land cover, 2015), water quality indicators being studied in different points of the basin. 


\section{Material and Method}

\subsection{Study Area}

The micro-basin of the Arizona River (Honduras), has a territorial extension of 216 hectares of which 155 hectares are of broad-leaved humid forest, 60 hectares are pastureland and one hectare of Arabica coffea (Figure 1). It limits, to the North with the community of Zanzibar ( $x 460465 ; y: 1736597)$ to the South with (x460872; $y$ : 1736112), to the East (x461024; y: 1736371) with the "old" water supply project to the municipality of Arizona and to the West with (x460017; y: 1736114).

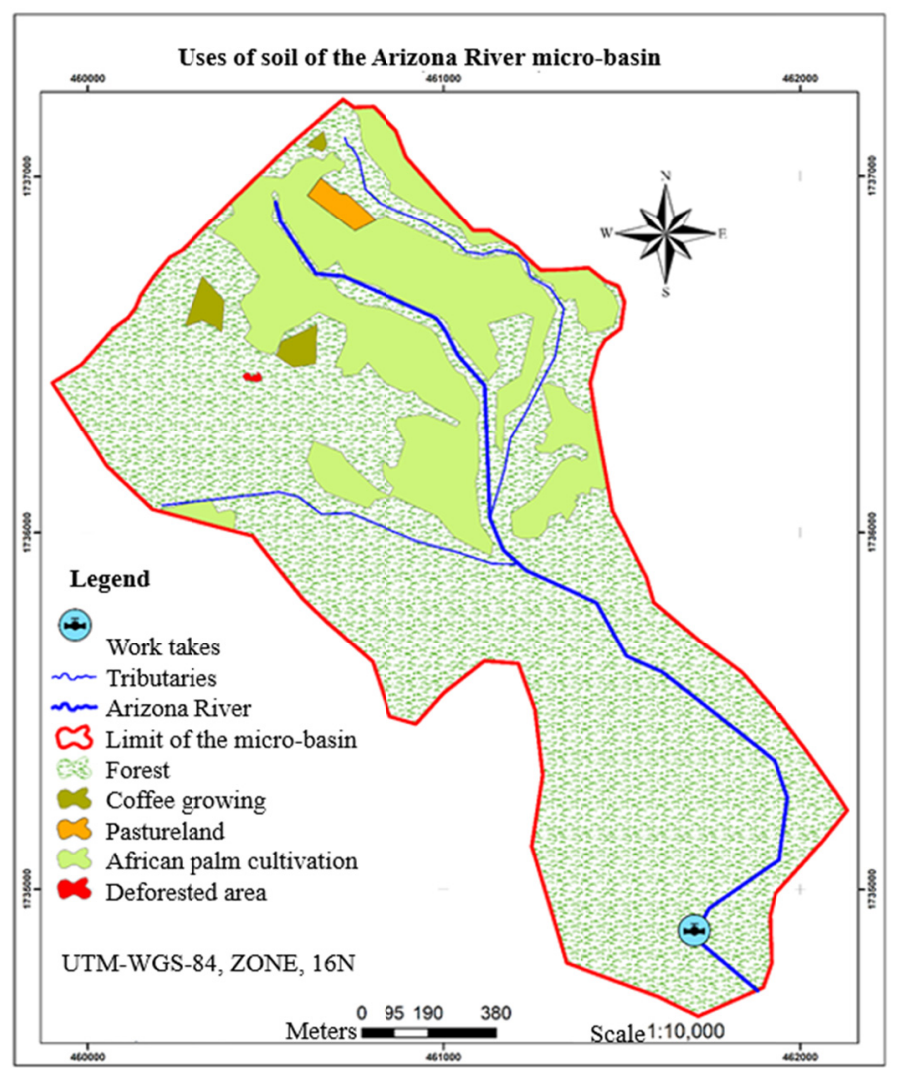

Figure 1. Land use in the Arizona River micro-basin

\subsection{Water Quality Analysis}

\subsubsection{Sampling Points}

Different sampling points were made: one in the construction site of the project, point number two in the storage tank, the third, fourth and fifth point were executed in three faucets distributed in the south-east and south-west of the urban area in the municipality of Arizona, the first tap at the start of the distribution network, the second tap in the intermediate zone and the last tap in the final part of the project distribution network.

\subsubsection{Parameters of Water Quality According to the Calculation of ICA}

The physical and chemical parameters measured were temperature, $\mathrm{pH}$, nitrates, total phosphorus, total dissolved solids and total dissolved oxygen, according to the methodology described by Macêdo (2005).

\section{(1) Temperature}

The temperature was determined in the field, using a digital thermometer. It is a parameter that measures the intensity of heat, reflected in the degree of water heating and depends on environmental factors such as geological composition, electrical conductivity and climate (Matic et al., 2013).

\section{(2) Hydrogen Potential}

The $\mathrm{pH}$ is an important parameter in water quality, since its value in both natural waters and wastewater indicates all the equilibria that are established in the water, being a parameter that besides controlling most of the reactions 
chemical, controls biological activity, where in most cases, it is only possible for $\mathrm{pH}$ values between 6-8 (De Souza, 2001).

\section{(3) Disolved Oxygen}

Dissolved oxygen (DO) is one of the most important water quality parameters, since it indicates the contamination of the same, being that the waters that present low values of DO, are caused by the presence of organic matter or material oxidized, demanding in these cases, a demand for oxygen, either for the respiration of microorganisms capable of digesting organic matter or to oxidize inorganic matter, being that such demand can exhaust or diminish the OD (Posada et al., 2013). It is a parameter that in water depends on the atmospheric pressure and the temperature of the water, according to Henry's law.

\section{(4) Nitrates}

Nitrates, is the most stable form of nitrogen dissolved in water, whose concentration in natural waters is in concentrations of approximately $1.0 \mathrm{~g} \mathrm{~L}^{-1}$ (Shelton, 1999). Within the metabolism of ecosystems, nitrogen is the most important element, since it is related to the formation of proteins, one of the basic components of biomass.

(5) Total Phosphorus

Phosphorus is another element that leads to the determination of water quality, because when it is found in high concentrations in surface water, it leads to the eutrophication process, causing an increase in water turbidity (M. J. Hammer \& M. J. J. Hammer, 2003).

\section{(6) Total Dissolved Solids}

The total dissolved solids parameter refers to the matter suspended or dissolved in water, that is, a parameter that measures the total filterable solid waste through a membrane of $2.0 \mu \mathrm{m}$. This parameter is decisive for the quality of the waters, since when there are waters with a high concentration of total solids, they generate bad taste for the palate and induce an adverse reaction for the consumer. This parameter is at the same time an indicator of the effectiveness of biological and physical wastewater treatment processes.

\section{(7) Turbidity}

Turbidity is another of the relevant analytical parameters in water quality, since it is a parameter that reflects the quantity of colloidal, mineral and organic materials, indicating the presence of contamination (Espigares \& Fernández-Crehuet, 1999). In water for human consumption, high levels of turbidity, can protect microorganisms from the effects of disinfection, stimulating the proliferation of bacteria and, accordingly, increase the demand for chlorine. Other substances that increase turbidity in water are the presence of humic substances or heavy metals in water (Macó et al., 2004).

\subsubsection{Biological Parameters Analyzed}

Regarding the biological parameters determined were thermotolerant coliforms and biochemical oxygen demand (BOD).

\section{(1) Thermotolerant Coliforms}

Thermotolerant coliforms, also known as fecal coliforms, encompass the species of bacteria found in the intestinal tract of both humans and warm-blooded animals, and can be differentiated into total and fecal coliforms (Silva et al., 2006). In water, it is an important parameter to evaluate the deficient hygienic-sanitary conditions, since this type of bacteria, is constituted by bacteria like Escherichia coli.

\section{(2) Biochemical Oxygen Demand (BOD)}

The chemical oxygen demand (COD) is one of the most important biological indicators to determine the quality of drinking water, being used as a measure of the amount of oxygen required for the oxidation of biodegradable organic matter, present in the water sample. action of aerobic oxidation (Ramalho, 2003). It was determined at incubation temperature of $20^{\circ} \mathrm{C}$, for 5 days, expressed as $\mathrm{mg} \mathrm{L}^{-1} \mathrm{O}_{2}$ known as $\mathrm{BOD}_{5}$.

\subsubsection{Formula Used for Determining the Water Quality Index of the Microbasin}

Once the chemical and biological parameters were determined, they were introduced into the equation proposed by Brown et al. (1990), to determine the water quality index (ICA) of the National Sanitation Foundation (NSF), according to Equation (1):

$$
\mathrm{ICA}=\sum_{\mathrm{i}=1}^{\mathrm{n}} \mathrm{qi} \cdot \mathrm{wi}
$$

where, $\mathrm{n}$ = parameters; $\mathrm{wi}$ = relative weights of each parameter; $\mathrm{q} i=$ subscript of parameter $\mathrm{i}$. 
Finally, the value obtained from the multiplicative weighted function is interpreted by the ICA classification proposed by Brown.

\section{Results and Discussion}

To evaluate the quality of the water, samples were taken from different points: the first point was at the construction site of the project, point number two in the storage tank, the third, fourth and fifth point, in faucets distributed in the South zone -This and South-West of the urban area of the municipality of Arizona and the last tap in the final part of the distribution network of the project.

Table 1. Water quality index (ICA) of the Arizona River micro-basin

\begin{tabular}{|c|c|c|c|c|c|c|c|c|c|}
\hline \multirow{2}{*}{ Parameter } & \multicolumn{3}{|c|}{ Sampling I } & \multicolumn{3}{|c|}{ Sampling II } & \multicolumn{3}{|c|}{ Sampling III } \\
\hline & Original reading & $\mathbf{Q}$ & ICA & Original reading & $\mathbf{Q}$ & ICA & Original reading & $\mathbf{Q}$ & ICA \\
\hline Thermotolerant coliforms (UFC/100 mL) & 650 & 28 & 4.2 & 364 & 30 & 4.5 & 180 & 40 & 6 \\
\hline $\mathrm{pH}$ & 7.43 & 93 & 11.16 & 6.85 & 80 & 9.6 & 7.78 & 90 & 10.8 \\
\hline $\mathrm{BOD}\left(\mathrm{mg} \mathrm{L}^{-1}\right)$ & 0.99 & 90 & 9 & 0.99 & 93 & 9.3 & 0.99 & 93 & 9.3 \\
\hline Nitrates $\left(\mathrm{mg} \mathrm{L}^{-1}\right)$ & 0 & 0 & 0 & 1.07 & 91 & 9.1 & 0 & 0 & 0 \\
\hline Total phosphate (mg L $\left.{ }^{-1}\right)$ & 0.01 & 42 & 4.2 & 0.02 & 93 & 9.3 & 0.05 & 100 & 10 \\
\hline Temperature $\left({ }^{\circ} \mathrm{C}\right)$ & 22 & 9 & 0.9 & 22 & 9 & 0.9 & 22 & 9 & 0.9 \\
\hline Turbidity (UNT) & 4.87 & 87 & 6.96 & 1.1 & 97 & 7.76 & 2.32 & 95 & 7.6 \\
\hline T.D.S. $\left(\mathrm{mg} \mathrm{L}^{-1}\right)$ & 66 & 86 & 6.88 & 5 & 81 & 6.48 & 37 & 84 & 6.72 \\
\hline \multirow[t]{2}{*}{ Dissolved oxigen $\left(\mathrm{mg} \mathrm{L}^{-1}\right)$} & 9.35 & 5 & 0.85 & 8 & 6 & 1.02 & 8.1 & 4 & 0.68 \\
\hline & & & 44.15 & & & 57.96 & & & 52 \\
\hline
\end{tabular}

In Table 1, the values of the ICA are presented for the three samplings made in the Arizona River micro-basin, obtaining the mean value of 51.37. Depending on the value obtained in the ICA, it is necessary to carry out a type of treatment in the water or another, since for high values obtained from the ICA (90-100), it means that the water will need a lower treatment than others with values lower (50-90) in which they must be subjected to an additional treatment (Torres, Cruz, \& Patiño, 2009) as is the case of the value obtained in this work, this being considered in accordance with ICA of the NSF as regular, having that to be carried out a purifying treatment for that water to be consumed. In accordance with Honduran legislation, in the national technical standard for drinking water quality in 1995 , the temperature is within the limits established by this legislation that establishes that it must be between $18-30^{\circ} \mathrm{C}$, with the temperature in this work of $22{ }^{\circ} \mathrm{C}$.

Regarding the $\mathrm{pH}$ value, the norm establishes that it should be between $6.5-8.5$, being within the parameters. The value of turbidity, the norm establishes that it must be less than one, being in this work with values higher than those established, especially in the first reading whose value is 4.87 UNT. The high value for turbidity in the first reading, may be due to the presence of sediments from the upper part of the micro-basin caused by the opening of an access road to the community of Zanzibar.

The levels of nitrates in the water for human consumption, according to the norm, are established recommended concentrations of $25 \mathrm{mg} \mathrm{L}^{-1}$, being the maximum tolerable value of $50 \mathrm{mg} \mathrm{L}^{-1}$, and for this work, no detectable concentrations of nitrate were found in water, which may be due to the organic matter acting as an interferent.

For the biological parameters, the norm says that coliforms should not exist, being found in this work values superiors to the allowed ones, being able to be due to certain type of anthropogenic contamination.

In Table 2, the values of different parameters for taps and water storage tank are presented.

Table 2. Physicochemical and biological parameters for taps and tank

\begin{tabular}{|c|c|c|c|c|c|c|c|c|c|c|c|c|}
\hline \multirow{2}{*}{ Parameter } & \multicolumn{3}{|c|}{ Tap 1} & \multicolumn{3}{|c|}{ Tap 2} & \multicolumn{3}{|c|}{ Tap 3} & \multicolumn{3}{|c|}{ Tank } \\
\hline & Read 1 & 1 Read 2 & 2 Read 3 & Read 1 & Read 2 & Read 3 & Read 1 & Read 2 & Read 3 & Read 1 & Read 2 & Read 3 \\
\hline Coliformes termotolerantes (UFC/100 mL) & 818 & 455 & 22 & 100 & 150 & 141 & 2500 & 682 & 21 & 521 & 2200 & 14 \\
\hline True color $(\mathrm{mg} \mathrm{Pt}-\mathrm{Co} / \mathrm{L})$ & 4.59 & 5.00 & 5.00 & 4.59 & 10.00 & 5.00 & 31.00 & 5.00 & 4.59 & 4.59 & 5.0 & 5.0 \\
\hline Turbidity (UNT) & 6.84 & 1.00 & 2.53 & 5.64 & 1.50 & 2.89 & 23.25 & 1.50 & 2.33 & 4.49 & 1.60 & 2.71 \\
\hline $\mathrm{pH}$ & 7.58 & 7.36 & 7.55 & 7.45 & 6.90 & 7.85 & 7.24 & 7.10 & 7.76 & 7.40 & 6.99 & 7.77 \\
\hline $\mathrm{T}\left({ }^{\circ} \mathrm{C}\right)$ & 24.00 & 25.00 & 24.00 & 24.50 & 25.00 & 25.00 & 26.00 & 26.00 & 25.00 & 22.00 & 23.00 & 24.00 \\
\hline
\end{tabular}


The first parameter analyzed in Table 2 was that of thermotolerant coliforms, which have values higher than those allowed by the technical regulation for drinking water quality in Honduras, 1995, being attributed to anthropogenic activities carried out in the upper and middle part of the micro-basin, which present a danger to the water-consuming population of this project. The presence of thermotolerant coliforms in surface waters is directly related to runoff from rainfall and areas washed by irrigation (Brooks et al., 1991).

Also the high contents of sedimentation found in the distribution network is the effect of erosion by runoff due to overuse of the soil in the upper part of the micro basin that alter the levels of thermotolerant coliforms present in the taps and tank storage. In the third sampling conducted, the levels of Colmiform Thermotolerant decreased significantly this is attributed to the efficiency of purging or cleaning the distribution pipes made by the water board of the municipality of Arizona to the distribution network in which considerable amounts of sedimentation were drained themselves that are hosts of bacterial colonies.

As for the true color, the legislation establishes as recommended value $1 \mathrm{mg}$ Pt-Co. $\mathrm{L}^{-1}$ and admissible up to a value of $15 \mathrm{mg} \mathrm{Pt}-\mathrm{Co}_{\mathrm{L}} \mathrm{L}^{-1}$. In this work all are in agreement with the norm, except the first sampling of tap number 3, attributed to activities carried out in the upper part of the micro-basin which affect soil erosion, for this reason they generate changes in the color of the water, also influences the location of tap number three given that it is a residential area that only three houses exist, therefore the volume of water retained during considerable time in the distribution network is greater than the consumption presented in this area.

The maximum values allowed by the standard, for the levels of turbidity, are established in that this can not exceed the value of 1 UNT, being in this work higher than those allowed. This can be caused by the high concentration of sediments found in the water network of the "new" project.

The measured $\mathrm{pH}$ values are according to the norm, where it states that the $\mathrm{pH}$ values must be between $6.5-8.5$ and the same happens with the temperature.

These results are attributed to the presence of $71 \%$ of vegetation in the micro-basin, for this reason the water temperature is maintained in considerable ranges, also distance from the work it takes to the storage tank influences given that it is only $1.5 \mathrm{~km}$ consequently affects to maintain these temperatures.

\subsection{Statistic Analysis}

In Figure 2, the scores for the variables studied are presented.

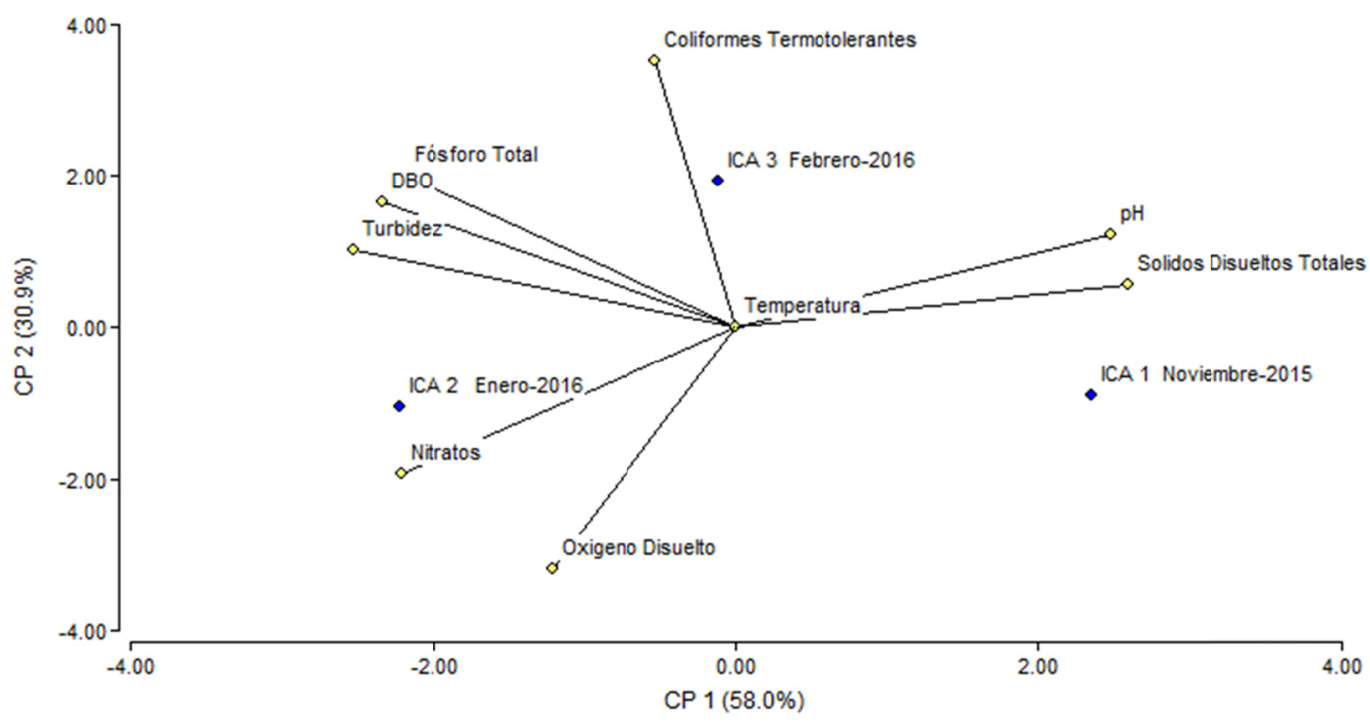

Figure 2. Principal Component Analysis for ICA

The main component number one (CP-1) with a $58 \%$ analysis of variance dictates that the Total Dissolved Solids, $\mathrm{pH}$ and Turbidity variables are directly related to the ICA 1 of the month of November of 2015. This is attributed to what is the rainy season in the area, therefore the levels of drag sediment by runoff tend to be higher. The ICA 2 of the month of January of the year 2016, presented a direct relation with the nitrates, this is due to the fact that 
there was no interference of organic matter in the sample, it was in that only sampling during the investigation that their presence was determined. In the (CP-2) with a $30.9 \%$ analysis of the variance describes that the Coliforms Thermotolerant had their lowest presence in ICA 3 of the month of February 2016, this low is attributed to the little sediment present in the Arizona River by the incidence of rains presented weeks after sampling. According to Brooks et al. (1991) The presence of thermotolerant coliforms in surface waters is directly related to the presence of sediments due to runoff from rains or other spills or anthropogenic activities. The temperature did not show significant variability during the three samplings was maintained in the average levels

\section{Conclusions}

According to the land use map of the micro-basin, it is evidenced mainly in the upper and middle part, that vocation lands that produce water, are being used for grazing and coffee growing activity that causes: deforestation, soil erosion and consequently, water pollution.

The most influential types of pollution in the water quality of the "new" project in Arizona are: bacteriological and the increase in turbidity is due to the anthropogenic activities carried out in the upper and middle part of the micro-basin, which influence the erosion of large amounts of sediment in the riverbed as a result of excessive deforestation in the micro-basin.

According to the results presented by the ICA of the NSF, in reference to the water quality of the work, the "new" project of the Arizona river micro-basin is regular with an index of 51.37.

\section{References}

ANA (Agência Nacional das Águas). (2005). Panorama da qualidade das águas superficiais no Brasil. Cadernos de Recursos Hídricos, 1 (p. 176). ANA/MMA: Brasília, DF.

ANA (Agência Nacional das Águas). (2018). Indicadores de qualidade-Índice de qualidade das águas (IQA).

Brooks, K. (1991). Hydrology and the management of watersheds (p. 392). Ames, IA USA. Iowa State University Press.

De Souza, E. R. (2001). Noções sobre qualidade da água. Instituto Superior Técnico, Departamento de Engenharia Civil e Arquitectura, Lisboa.

Espigares García, M., \& Fernández-Crehuet, M. (1999). Calidad del agua para consumo público: Caracteres físico-químicos. In J. A. Pérez López \& M. Espigares García (Eds.), En Estudio sanitario del agua (pp. 85-114). Editorial Universidad de Granada, Granada.

Esteves, F. A. (1988). Fundamentos de limnologia (p. 574). Rio de Janeiro, RJ: Editora Interciência, Finep.

Hammer, M. J., \& Hammer, M. J. J. (2003). Water and Wastewater technology (5th ed.). Prentice Hall, Inc.

Macedo, J. A. de B. (2005). Métodos laboratoriais de análises físico-quimicas e microbiológicas. Consejo Regional de Química-Minas Gerais.

Marcó, L., Azario, R., Metzler, C., \& Garcia, M. C. (2004). La turbidez como indicador básico de calidad de aguas potabilizadas a partir de fuentes superficiales. Propuestas a propósito del estúdio del sistema de potabilización y distribución en la ciudad de Concepción del Uruguay. Higiene y Sanidad Ambiental, 4, $72-82$.

Matic, N., Miklavcic, I., Maldini, K., Damir, T., Cuculic, V., \& Cardellini, C. (2013). ET AL. Geochemical and isotopic characteristics of karstic springs in coastal mountains (Southern Croatia). Journal of Geochemical Exploration, 132, 90-110. https://doi.org/10.1016/j.gexplo.2013.06.007

Posada, E., Mojica, D., Pino, N., Bustamante, C., \& Pineda, A. M. (2013). Establishment of environmental quality índices of rivers according to the behavior of disolved oxygen and temperature. Applied to the Medellin River, in the Valley of Aburra in Colombia. Dyna, 80(181), 192-200.

Ramalho, R. (2003). Tratamiento de Aguas Residuales. Barcelona: España, Editorial Reverté, S.A.

Rebouças, A. da C. (2002). Água doce no mundo e no Brasil. In A. Da C. Rebouças, B. Braga, \& J. G. Tundisi (Eds.), Águas doces no Brasil capitais ecológicos usos e conservação (3rd ed., pp. 269-324). São Paulo: Escrituras.

Shelton, B. (1999). Interpreting Drinking Water Quality Analvsis What Do the Numbers Mean Capturado em 02/04/00. Retrieved from http://www.Wabus.Com/gatnerer/interpret.html 
Torres, P., Cruz, C. H., \& Patiño, P. J. (2009). índices de calidad de aguas em fuentes superficiales utilizadas em la producción de agua para consumo humano: Uma revisión crítica. Revista Ingenieria Universidad de Medellín, 8(15), 79-94.

UNIAGUA (Universidade da Água). (2018). Água no Planeta. Retrieved from http://www.uniagua.org.br/ aguanoplaneta.htm

\section{Copyrights}

Copyright for this article is retained by the author(s), with first publication rights granted to the journal.

This is an open-access article distributed under the terms and conditions of the Creative Commons Attribution license (http://creativecommons.org/licenses/by/4.0/). 